\title{
Recent Context or Recent Conflicts: Bangladesh vs Myanmar Concerning the Matter Related to the Territorial Jurisdiction in the Sea Opened the Door of Sea Foods Production and Mining of Minerals, Gas and Oil
}

\author{
Shafora B. Ahsan ${ }^{1 *}$, M. Ahsan B. Habib ${ }^{2}$ \\ ${ }^{1}$ Voltex Battery Manufacturing Company Limited, Motijheel C/A, Dhaka, Bangladesh \\ ${ }^{2}$ Dept. of Aquaculture, Faculty of Fisheries, Bangladesh Agricultural University, Mymensingh, Bangladesh
}

\begin{abstract}
Territorial land and waters in sea is very important for a nation which increase the production of sea foods as fish \& sea weeds, mining of mineral \& important elements and gas \& oil. This territorial water harvours valuable rear minerals reserve, at least 100 trillion cubic feet gas for nearly 100 years \& good quantity of oil reserve, and different types of nutritionally rich fishes \& sea weeds more than 500 species. Nation should take care about the proper management and justified attributes with honest step for its border territory with other country. Bangladesh Govt. took a brilliant efforts for its own real territorial sea waters with Myanmar through a case with the United Nations (UN) convention to the International Tribunal for the Law Of the Sea in an international court (ITLOS) in Hamburg, Germany against Myanmar on December 14, 2009. The case was trialed for more than two years through many arguments and debts between the learned lawyers of both the countries. Finally Bangladesh won the case on March 14, 2012. It helped the nation for its sea fish and sea weeds production and catch. It was a great success and win for the present Govt. and the Excellency Honorable Prime Minister Sheikh Hasina as well as the people of Bangladesh.
\end{abstract}

KEY WORDS: Territorial Land; Sea; Elements; Gas, Oil; Fish; Sea Weeds

\section{INTRODUCTION}

There are many disputes along the border of Bangladesh with Myanmar and India which started after the independence of the country. The disputes with ocean territory is an important issues among the disputes which is rich with oil-gas blocks. There are about 28 sea gas blocks in this area including 20 in the deep sea [1]. In 2008, the oil-gas corporation (Petrobangla) of Bangladesh tried to lease 28 sea gas blocks including filed 20 in the deep sea located about 390 to 460 nautical miles away from the shore [1]. But Bangladesh bound to stop to lease these gas fields due to objection as well as opposition from the side of India and Myanmar Govt. Then Bangladesh filed a case against Myanmar with the United Nations (UN) convention to the International Tribunal for the Law Of the Sea (ITLOS) in Hamburg, Germany on December 14, 2009. Luckily both the countries agreed to obey the judgment of ITLOS. The final decision was taken by ITLOS on this dispute on sea border with Myanmar on March 14, 2012.

From six documents about recent conflicts on Bangladesh Myanmar territorial jurisdiction in the sea (Bay of Bengal), there are some important arguments were come up [2]. There are four documents came out for details about conflicts. There are two documents from Myanmar came up to discuss the counter-memorial and a rejoinder. However, due to lengthiness of the documents, discussion is made shortly at a glance. The first one is the fact that both Bangladesh and Myanmar has shifted from their traditional points of bargain in order to enhance their chances of winning the arbitration. This makes sense in the context of arbitration but I am skeptic about acceptance of this tactics in domestic politics of these countries - especially in Bangladesh. In case of Myanmar, the traditional line of claim has been the thin blue line, which is at around 243 degree azimuth. The bold line is at approx 230 azimuth that approximates the new equidistant line claimed by them. Bangladesh's traditional claim has been close to 180 degree azimuth line - depicted by bold red line, but the claim at the court has been made in favor of an angular bisector at 215 degree. My drawings are not perfect and I could not get any single image showing both claims properly in all those docs. So, the maps are not accurate. Bangladesh even went a step further and acknowledged that their earlier claims were based on 10 fathom territorial water claim in accordance to their 1974 law, but that has not been accepted in 1982 UNCLOS (Page 31-33). Hence, they are shifting from their claims made early. However a few ramifications from shift of stance are still evident - 


\section{International Journal of Current Science Research and Review}

ISSN: 2581-8341

Volume 04 Issue 05 May 2021

DOI: 10.47191/ijcsrr/V4-i5-21, Impact Factor: 5.825

IJCSRR@ 2021

www.ijcsrr.org

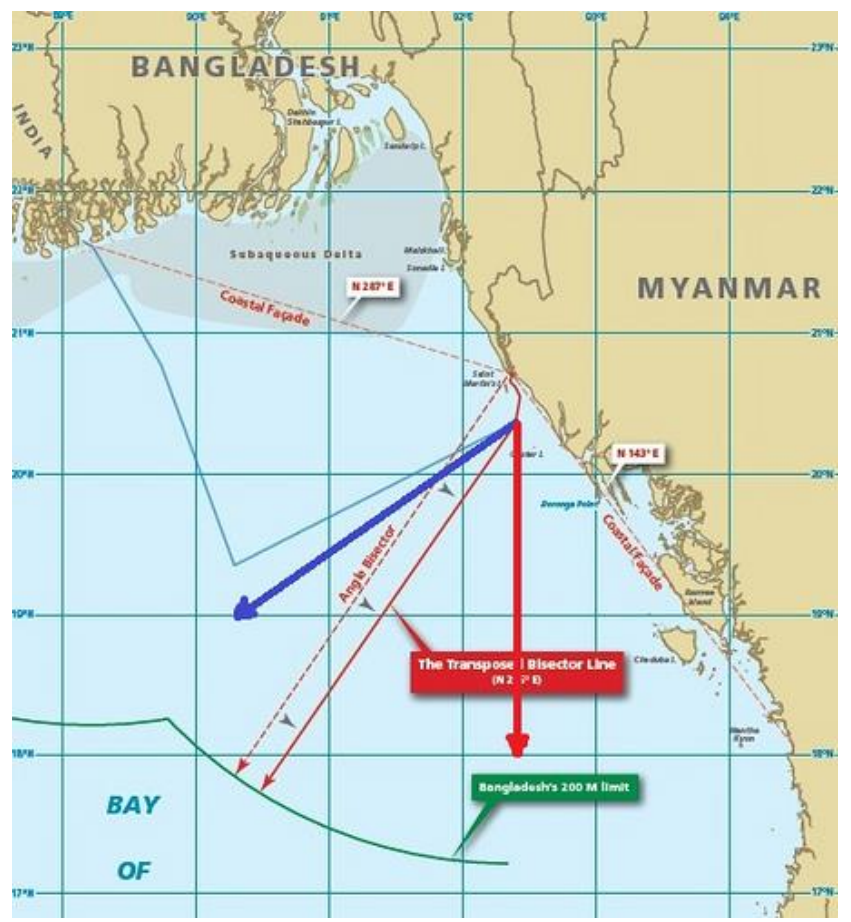

Map 1: Showing the territorial achievement of both Bangladesh and Myanmar

1) Even though Bangladesh Govt changed their stand, they never discussed it in public or even in front of media. The Bangladesh media is still publishing articles in favor of 1974 law that wrongly shows the Bangladesh claim to be a vertical line in map;

2) Even if Bangladesh wins the arbitration, they have to give up claims on significant amount of EEZ as perceived earlier. One of the consequences would be a few gas blocks, as published in maps, may have to be sacrificed. Based on my eye estimation and assuming this map is correct, I believe the blocks 23, 27 and 28 will not exist even after Bangladesh wins the arbitration. Subsequently, Bangladesh may have to amend its laws and/or constitution to reflect it; and

3) The dispute became less significant as the area under dispute has gone lower than estimated earlier (as perceived by Bangladesh media).

The matter is basically divided in three general categories. The first part deals with Territorial waters - that's within 12 NM of coastal boundary. The second part deals with next $200 \mathrm{NM}$ (nautical miles) - that's the EEZ boundary. The third one is beyond these two, that is called 'Continental Shelf' which is the reservoir of huge quantities of sea fish \& sea weeds, valuable minerals, gas and oil will bust the brightness of economy of Bangaldesh. Huge amount of foreign currency will be earned from exploitation of sea fish \& valuable weeds and minerals. One Territorial waters, Bangladesh is citing 1974 minutes of meeting to argue in favor of them. Myanmar is counter-arguing that the minutes of meeting doesn't have any legal validity and they have a different map for territorial waters.

On EEZ, the issue has been so far divided in the issue of equidistant vs equity. The Bangladesh team proposed an angular bisector method to resolve Bangladesh's issue of concavity and access to international waters. Myanmar insists that the equidistant line itself provides equitable results and court can not "refashion nature". The Bangladesh argument looks stronger on paper on this so far. However, they have to justify the angular bisector at the first place. The concavity arguments from Bangladesh is reasonable. The ratio of coastal length and EEZ area is still may not be quite bad to trigger an adjustment.

On continental shelf, Bangladesh wrote a lengthy piece on Bengal fan to prove how the Bay of Bengal can be geographically considered as a natural prolongation of Bangladesh mainland. Myanmar pinned their arguments on geometric features and other examples where the court has awarded continental shelf beyond the plate boundary. At the same time, Myanmar also argues that the court does not have jurisdiction over continental shelf but they don't point out why it should not affect other judgments (such as one on EEZs). 


\section{International Journal of Current Science Research and Review}

ISSN: 2581-8341

Volume 04 Issue 05 May 2021

DOI: 10.47191/ijcsrr/V4-i5-21, Impact Factor: 5.825

IJCSRR@ 2021

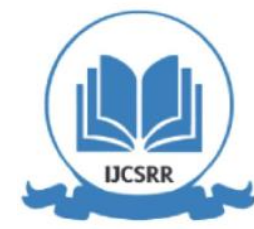

www.ijesrr.org

Both parties overall placed their arguments quite vigorously. Even though Bangladesh arguments look better on paper, I should remind the reader that Bangladesh is a plaintiff in this lawsuit, i.e. the burden of proof is on Bangladesh's shoulder. Unless they can convince the jury of something else, Myanmar might win it. There are a couple of takeaways for the other case Bangladesh is fighting - with India. First is that the claim from Bangladesh will be less in that case too, i.e. the overlapping aka disputed area would be even less. The second is that in case Bangladesh wins this case against Myanmar, they will lose their arguments that they don't have access to international waters or they are disadvantaged by concavity. An award in favor of Bangladesh would remove both constraints.

\section{JUDICIAL PROCEDURES}

After filing the case, the ITLOS started for hearing form September 08, 2011 when Bangladesh first placed its argument while Myanmar's arguments were heard from September 28 of the same year [1]. However, both the countries have agreed to obey the judgment of ITLOS in Hamburg, Germany.

\section{RESULTS}

In a historic victory at the UN maritime tribunal on March 14, 2012, Bangladesh has won territorial and economic rights to the vast Bay of Bengal resources even beyond it bargained for territorial waters [3]. "We have got all we wanted," an elated foreign minister told bdnews24.com on Wednesday by phone from Hamburg, Germany, where the ITLOS is based. Bangladesh got more than it claimed in its long-running dispute with Myanmar. Bangladesh claimed 107,000 square kilometers with while it got 111,000 square kilometers area in the Bay of Bengal. The foreign minister Dr. Dipu Moni said, "The court has given equitable solution on equidistance basis," immediately after the verdict. The map showing the boundary which Bangladesh and Myanmar achieved.

The president of the tribunal, Jose Luis Jesus of Cape Verde, prepared 151 pages report on judgment and read the summery of judgment entitled as "Bangladesh wins the maritime suit against Myanmar" in the Hamburg courtroom. The court also gave St Martin's a full effect. "The full effect means Bangladesh has the territorial and economic rights surrounding the island up to 200 nautical toward continental shelf in an angle of 215 degrees," an official explained. "The ITLOS ruling, by a vote of 21 to 1 , brings to a conclusion the case initiated by Bangladesh against Myanmar in December 14, 2009, to resolve a longstanding dispute with regard to the maritime boundary in the oil-and-gas rich Bay," says a statement from the foreign ministry in Dhaka." The court sustained Bangladesh's claims to a full 200 mile exclusive zone in the Bay of Bengal, and to a substantial share of the outer continental shelf beyond 200 miles. The foreign minister of Bangladesh said, "All of our strategic objectives have been achieved. Bangladesh's full access to the high seas out to 200 miles and beyond is now recognized and guaranteed, as are our undisputed rights to the fish in our waters and the natural resources beneath our seabed". The ITLOS awarded a full 12 miles territorial sea around St. Martin's Island to Bangladesh, but rejected Myanmar claim and argument was that it should be cut in half.

The judgment of ITLOS constituted the equitable solution which the nation desired from long time. It is a victory for both the nations because it finally resolved peacefully in accordance with the international law. However, Bangladesh should respect the honest willingness to resolve peacefully the matter by legal means and to accept the tribunal's judgment. The case was resolved within short time nearly two nears time. This is unprecedented for judicial efficiency in a maritime boundary case. During arguments, Myanmar had claimed that its maritime boundary with Bangladesh cut directly across the Bangladesh's maritime jurisdiction to a narrow wedge of sea not extending beyond 130 miles. Myanmar also claimed that the tribunal lacked jurisdiction to award continental shelf rights beyond 200 miles from either coast of the states. But the tribunal directly rejected both the claims. The 151 page judgment is for the first time that any court or tribunal to delimit the maritime area beyond 200 miles which known as 'outer continental shelf'.

Bangladesh got an opportunity to explore vast deposits of ores containing many valuable elements (minerals). The deposit types are in the form of (i) sulfides, (ii) crusts and (iii) nodules [4]. Estimates suggest that the area of Bay of Bengal holds more elements (metals) than do land deposits. Different valuable minerals are - gold, platinum, silver, copper, lead, zinc, nickel, manganese, phosphorus, calcium, molybdenum, vanadium, lithium, cobalt, tungsten, arsenic, bismuth, platinum group metals, tellurium, thallium, thorium etc. The companies are exploring the potentials to mine three types of deposits in the sea: (i) Ferromanganese nodules; (ii) Metal-rich crusts on seamounts and (iii) Sulfide deposits near hydrothermal vents along the mid- 


\section{International Journal of Current Science Research and Review}

ISSN: 2581-8341

Volume 04 Issue 05 May 2021

DOI: 10.47191/ijcsrr/V4-i5-21, Impact Factor: 5.825

IJCSRR@ 2021

Www.ijcsrr.org

ocean ridges. Most commercial attention is focused on the nodules exploration. Another two important resources are - natural gas and oil where the zone reserves about 100 trillion cubic feet gas for 100 years and huge quantity of oil reserve. It also herbours more than 500 valuable nutritionally rich fishes and sea weeds species [5].

\section{CONCLUTION}

It's a great territorial win of Bangladesh perhaps for the first time so far known through ITLOS, Hamburg, Germany. But Myanmar Govt. can get selute for accepting the judgment peacefully which opened the door to stay as a good friendly neighbour. This wonderful achievement happened due to real judgment and tired less activities of Bangladesh Government. The Bangladesh Govt. tried hard since the inception of the case in 2009. The high official specially honourable the then Foreign Minister Dr. Dipu Moni and others of Govt. sincerely worked very hard for success in different ways since its first trial. The foreign Minister gave untired efforts to win the case and she have done a lot of meaningful activities in favour of the country. She faced a lot of problems and queries during the trial.. But she was not hopeless or thought to withdraw themselves from the race with Myanmar. To make a successful achievement, excellency honourable prime minister Sheikh Hasina always took care and all the noble and fruitful steps done to win the case. Her excellency made a targeted effort regarding the win of this case as well as to defeat Myanmar Govt. successfully. The untired help and cooperation of her excellency honourable prime minister ultimately helped exforeign minister Dr. Dipu Moni and other high officials of Ministry to win the case and got the territorial sea waters of Bangladesh. The people of Bangladesh became so happy for this win. It will remain as a historic honest and noble win for a legal dispute which is an example to be followed by other countries who are facing problems for their territory, territorial sea waters and forest.

It has been observed that there were some problems also found in the past with India related to 'Chit Mohal', transit, shares of water of different rivers, border issues and territory. There were serious long past problems related to 'Chit Mohan' prevailed since the independence of these two naubouring countries - Bangladesh and India. It was solved during the resume of present Govt. very amicably and peacefully where India handed over nearly 1100 acres 'Chit Mohan' land to Bangladesh and Bangladesh handed over about 700 acres Chit Mohan to India. We hope that other territorial disputes like share of water of different rivers with India will be honestly solved very soon.

\section{REFERENCE}

1) The New Nation. Dhaka, Bangladesh. March 14, 2012. p 1. www://bdnews24.com

2) www://ITLOS

3) The New Nation. Dhaka, Bangladesh. March 15, 2012. p 1-2. www://bdnews24.com

4) www.natural.com/articles/d41586-019-02231-1

5) www.waterencyclopedia.com

Cite this Article: Shafora B. Ahsan, M. Ahsan B. Habib (2021). Recent Context or Recent Conflicts: Bangladesh vs Myanmar Concerning the Matter Related to the Territorial Jurisdiction in the Sea Opened the Door of Sea Foods Production and Mining of Minerals, Gas and Oil. International Journal of Current Science Research and Review, 4(5), 470-473 